\title{
GENOTYPE CHARACTERIZATION OF THE Haematobia irritans (DIPTERA: MUSCIDAE) FROM BRAZIL, DOMINICAN REPUBLIC AND COLOMBIA BASED ON RANDOMLY AMPLIFIED POLYMORPHIC DNA (RAPD) ANALYSIS*
}

\author{
LUCIANA GATTO BRITO ${ }^{1}$; LUCIANA C. DE A. REGITANO ${ }^{2}$; MARIBEL ELIZABETH F. HUACCA ${ }^{3}$; EMANUEL \\ CARRILHO $^{3}$; MARIA JOSÉ PAES ${ }^{4}$; GONZALO E. MOYA- BORJA ${ }^{5}$
}

\begin{abstract}
BRITO, L.G; REGITANO, L.C. DE A.; HUACCA, M.E.F.; CARRILHO, E.; PAES, M.J.; MOYABORJA, G.E. Genotype characterization of the Haematobia irritans (Diptera: Muscidae) from Brazil, Dominican Republic and Colombia based on randomly amplified polymorphic DNA (RAPD) analysis. [Caracterização genotípica de Haematobia irritans (Diptera: Muscidae) procedentes do Brasil, República Dominicana e Colômbia baseada na análise do DNA polimórfico amplificado ao acaso (RAPD)]. Revista Brasileira de Parasitologia Veterinária, v.17, n. 4, p.179-184, 2008. Embrapa Rondônia, Caixa Postal 406, Porto Velho, RO 78900970, Brazil. E-mail: luciana@cpafro.embrapa.br.

Blood-sucking flies are important parasites in animal production systems, especially regarding confinement conditions. Haematobia irritans, the horn fly, is one of the most troublesome species within bovine production systems, due to the intense stress imposed to the animals. $H$. irritans is one of the parasites of cattle that cause significant economic losses in many parts of the world, including South America. In the present work, Brazilian, Colombian and Dominican Republic populations of this species were studied by Random Amplified Polymorphic DNA (RAPD) to assess basically genetic variability between populations. Fifteen different decamer random primers were employed in the genomic DNA amplification, yielding 196 fragments in the three $H$. irritans populations. Among $H$. irritans samples, that from Colombia produced the smallest numbers of polymorphic bands. This high genetic homogeneity may be ascribed to its geographic origin, which causes high isolation, low gene flow, unlike the other American populations, from Brazil and Dominican Republic. Molecular marker fragments, which its produced exclusive bands, detected in every sample enabled the population origin to be characterized, but they are also potentially useful for further approaches such as the putative origin of Brazilian, Colombian and Dominican Republic populations of horn fly from South America. Similarity indices produced by chemo metric analysis showed the closest relationships between flies from Brazil and Dominican Republic, while flies from Colombia showed the greatest genotypic differentiation relative to the others populations.
\end{abstract}

KEY WORDS: Horn fly, genetic diversity, molecular markers, American populations.

\section{RESUMO}

Moscas hematófagas são importantes parasitas em sistemas de produção animal, especialmente em condições confinamento. Haematobia irritans, a mosca-dos-chifres, é uma das espécies

\footnotetext{
*Supported by CAPES.

${ }^{1}$ Embrapa Rondônia, Caixa Postal 406, Porto Velho, RO, 78900-970, Brazil. E-mail: luciana@cpafro.embrapa.br

${ }^{2}$ Embrapa Pecuária Sudeste, Cx. Postal 339, São Carlos, SP 13560970, Brazil.

${ }^{3}$ Instituto de Química de São Carlos, Universidade de São Paulo (IQSC/ USP), Cx. Postal 780, São Carlos, SP 13540-910, Brazil.

${ }^{4}$ Instituto Universitário do Norte Matogrossense, Universidade Federal de Mato Grosso, Avenida Brasília, 1200-B, Distrito Industrial, Sinop, MT, 78550-000, Brazil.

${ }^{5}$ Departamento de Parasitologia Animal, Universidade Federal Rural do Rio de Janeiro, Seropédica, RJ 23890-000, Brazil.
}

que mais causam problemas em sistemas de produção de bovinos, devido ao intenso estresse que impõe aos animais. $H$. irritans é um dos parasitas de bovinos que determinam as maiores perdas econômicas, as quais são significativas em muitas partes do mundo, incluindo a América do Sul. No presente trabalho, populações desta espécie provenientes do Brasil, Colômbia e República Dominicana foram estudadas através da análise do DNA polimórfico amplificado ao acaso (RAPD) para avaliar basicamente a variabilidade genética entre as populações. Quinze diferentes iniciadores decamétricos aleatórios foram utilizados na amplificação do DNA genômico, produzindo 196 fragmentos nas três populações de $H$. irritans. Entre as amostras de $H$. irritans, a população proveniente da Colômbia foi a que produziu o menor número de bandas polimórficas. 
Esta alta genética homogeneidade pode ser atribuída à sua origem geográfica, provocada pelo grande isolamento e o baixo fluxo gênico, ao contrário das outras populações americanas, Brasil e República Dominicana. Fragmentos marcadores moleculares, que produzem bandas exclusivas, foram detectados em cada amostra, o que permitiu caracterizar a origem das populações, mas tais marcadores também são potencialmente úteis para outras abordagens, tais como a provável origem das populações brasileiras, colombianas e dominicanas na América do Sul. Índices de semelhança produzidos por análise quimiométrica revelaram uma relação mais estreita entre moscas do Brasil e da República Dominicana, enquanto que as moscas da Colômbia apresentaram a maior diferenciação genotípica em relação às outras populações.

PALAVRAS-CHAVE: Mosca-do-chifre, diversidade genética, marcadores moleculares, populações americanas.

\section{INTRODUCTION}

The horn fly Haematobia irritans was described by Linnaeus in 1758 and recognized as a bovine plague in France in 1830. The species H. irritans is an exotic fly in the Americas, which has been introduced from animals, imported by the United States from Europe in the XIX century, around 1884 and 1886, and has spread throughout North America. In the beginning of the XX century $H$. irritans could already be found in the Caribbean Islands and in the year of 1937 this flies entered the South American continent through Colombia (CAMPBELL; THOMAS, 1992). The presence of Haematobia irritans in Brazil, popularly known as "horn fly", has been detected since 1970's (VALÉRIO; GUIMARÃES, 1983).

Both geographical and temporal expansion of the horn fly in American countries have been directly related to the cattle movement, either to slaughter facilities or to other commercial purposes, without obeying any animal sanitary vigilance criteria, resulting in the presence of this parasite in the majority of the continent's countries.

The horn fly is the primary economic pest of beef cattle in the United States, costing producers with pastured cattle an estimated US\$ 876 million annually (KUNZ et al., 1991).

Haematobia irritans is an economically important obligate bloodfeeding ectoparasite of cattle (PALMER; BAY, 1981). Parasitism of cattle by an economic level of horn flies can result in reduced weaning weight, reduced weight gain as a result of decreased feed efficiency, and decreased milk production (DRUMMOND, 1987; STEELMAN et al., 1991; BYFORD et al., 1992). In addition, diminished leather quality can result from intense horn fly feeding (GUGLIELMONE et al., 1999). Therefore, control of the horn fly is a major economic problem for producers.

The abundance of genotypes within and among populations involves two different but related components: demographic and genetic structure. Demographic structure refers to processes influencing the number and distribution of phenotypical classes of individuals. The second component in population structure is genetic structure, which can be described as the genetic variation distribution resulting from the action of factors such as migration, selection, mutation and genetic derives. Demographical aspects are included in genetic processes, what allows the use of the genetic structure to infer the history and the demographic processes of the species. Direct demographic structure studies are particularly difficult in natural conditions, converting genetic data in the best or even only data available to study some demographical aspects, such as migration among multiple populations (RODERICK, 1996).

In a study conducted by Castiglioni-Ruiz (2001) different populations of $H$. irritans from four different Brazilian locations (two in São Paulo state, one from Mato Grosso do Sul state and one from the Acre state) were compared, along with an American sample from Texas (USA) using the technique of RAPD-PCR. The author has found similar results regarding similarity indexes of the populations studied, including the sample from the USA.

A RAPD locus as described here consists of a set of co migrating RAPD fragments amplified by the same RAPD primer (SKROCH; NEINHUIS, 1995).

In the present study, the RAPD-PCR has been used to analyze the genetic variability of populations of $H$. irritans from Brazil, Dominican Republic, and Colombia to evaluate the genotypic similarity of the populations studied and also to get a RAPD marker capable of identifying the geographical origin of each population.

\section{MATERIALS AND METHODS}

Origin of the samples, DNA extraction and quantification

To obtain the Brazilian sample, DNA from specimens of H. irritans from Roraima, Rio Grande do Norte, Mato Grosso do Sul, Rio de Janeiro and Rio Grande do Sul states have been mixed in equal parts and then homogenized. The Colombia and Dominican Republic samples were obtained from specimens of $H$. irritans from these countries.

Genomic DNA from 150 flies was used, 50 specimens from each analyzed country. DNA extraction was done through groups of five flies, with 10 repetitions for each country. The genomic DNA extraction protocol from the five individuals groups followed the technique described by Dellaporta et al. (1983), with some modifications.

Quantification of genomic DNA from samples was obtained by using a spectrophotometer. Through the absorbance obtained, it was possible to determine DNA concentration in solution $(\eta \mathrm{g} / \mu \mathrm{L})$ using the calculation: [DNA] $=\mathrm{OD} 260 \times 2500$. The purity of the preparations containing DNA was analyzed through the ratio between the readings done at the wavelengths of 260 and $280 \mathrm{\eta m}$.

The samples were then diluted in such a way that each PCR amplification reaction contained 25 çg of DNA per $\mu \mathrm{L}$.

\section{DNA amplification}

PCR amplifications were done in a termocycler according to the protocol described by WILLIAMS et al. (1990), using 
RAPD 10 mer primers (Operon Technologies, Alameda, CA). Working solutions containing $20 \mathrm{mM}$ of each primer diluted in sterile deionized water were prepared and stored at $-20^{\circ} \mathrm{C}$.

In the samples to be amplified, $3.0 \mathrm{~mL}$ primer and $25.0 \mathrm{çg}$ DNA were used, in $15.0 \mathrm{~mL}$ reaction volume. In order to detection the polymorphisms generated for RAPD, it was used Agilent Bionalyzer able to process approximately up to 12 samples of $1 \mathrm{~mL}$ in 30 minutes. All experiments with the amplicons were performed using Agilent Biosizing software (version A.01.10).

\section{Selection of RAPD primers}

Samples of different American populations of horn flies were amplified with 60 RAPD primers. The amplicons were assessed for the number and quality of polymorphic loci. All samples were amplified twice to verify patterns and reproducibility. RAPD loci were scored as 0 (band absent) or 1 (band present).

\section{Data analysis}

The gel images were analyzed using Kodak Eletrophoresis Documentation and Analysis System 290 (EDAS 290 - Kodak, Inc.) for estimation of the molecular weights of bands. Scoring of RAPD bands was done considering (1) or absence (0) of a determined DNA fragment for different samples. The presence of a determined band (similar size) in all genotypes compared indicates similarity, while the presence in one absence in other indicates dissimilarity. The data were analyzed by statical program NTSYS (Numerical Taxonomy and Multivariate Analysis System) (ROHLF, 1992). A pairwise similarity matrix between genotypes was generated using the JACCARD coefficient (JACCARD, 1901). The similarity coefficient, $J=a / a+b+c$, were: $a$ is the number of positives bands shared by both individuals $x$ and $y, b$ and $c i$ are the numbers of fragments present in individuals $x$ and $y$. The SAHN clustering program was then used to group the entries based on similarity coefficients using the unweighted pair-group method using arithmetic average (UPGMA).

From similarity indexes matrix obtained from data of the polymorphics bands generated by RAPD, chemo metric analysis was performed using EINSIGHT 3.0 software (Infometrix Inc., Seattle, WA), which uses hierarchical groups analysis methods as well as the main components and through the construction of dendogram makes it possible to observe the interrelations among the several analyzed genotypes and also to estimate the Euclidean distance among the samples.

To estimate the genotype distance among American populations of $H$. irritans was used the Penrose method, which tests multivaried distances of two or more populations considering data as medium, variance and covariance, and also Mahalanobis, which considers the correlation among variables, besides the numeric values used in Penrose test (AYRES et al., 2000).

\section{RESULTS AND DISCUSSION}

The genomic DNA amplification of horn fly populations using the 15 RAPD selected primers produced 196 fragments. These fragments varied from 2,020.2 to $204.8 \mathrm{bp}$. The total
Table 1. Random amplified polymorphic DNA primers used and number of fragments generated in American populations of horn fly.

\begin{tabular}{|c|c|c|c|c|}
\hline \multirow{2}{*}{$\begin{array}{c}\text { Primer } \\
\text { E1 }\end{array}$} & \multicolumn{3}{|c|}{ Nucleotide Sequence } & \multirow{2}{*}{$\begin{array}{c}\begin{array}{c}\text { Number of } \\
\text { RAPD bands }\end{array} \\
16\end{array}$} \\
\hline & 5 & CCCAAGGTCC & 3 & \\
\hline E5 & $5^{\prime}$ & TCAGGGAGGT & 3 & 14 \\
\hline E6 & $5^{\prime}$ & AAGACСССТC & 3 & 19 \\
\hline E12 & $5^{\prime}$ & TTATCGCCCC & 3 & 14 \\
\hline E15 & $5^{\prime}$ & ACGCACAACC & 3 & 13 \\
\hline $\mathrm{G} 2$ & $5^{\prime}$ & GGCACTGAGG & 3 & 08 \\
\hline G8 & $5^{\prime}$ & TCACGTCCAC & 3 & 10 \\
\hline G10 & $5^{\prime}$ & AGGGCCGTCT & 3 & 14 \\
\hline G16 & $5^{\prime}$ & AGCGTCCTCC & 3 & 15 \\
\hline G18 & 5 & GGCTCATGTG & 3 & 13 \\
\hline $\mathrm{H} 2$ & $5^{\prime}$ & TCGGACGTGA & 3 & 13 \\
\hline $\mathrm{H} 6$ & $5^{\prime}$ & ACGCATCGCA & 3 & 13 \\
\hline $\mathrm{H} 9$ & $5^{\prime}$ & TGTAGCTGGG & 3 & 09 \\
\hline $\mathrm{H} 12$ & $5^{\prime}$ & ACGCGCATGT & 3 & 13 \\
\hline $\mathrm{H} 19$ & $5^{\prime}$ & CTGACCAGCC & 3' & 12 \\
\hline Total & & & & 196 \\
\hline
\end{tabular}

number of bands produced by each primer varied from eight (primer G2) to 19 (primer E6). Regarding the total number of bands produced by population, the most polymorphic were Brazil (BR) and Dominican Republic (DR), each one with 67 bands, followed by Colombia (CO) with 62 bands (Table 1 ).

A 0/1 matrix for all 15 primers selected was generated by compiling only those frames which showed a 1 within the individual primer frameworks. The resulting cluster analysis revealed two major clusters that not correlated completely with the origin of samples. The program sharpened the samples which were not aligning in the analysis, which were considered as outliers, this analysis was based on similarity among samples (Figure 1). The exclusion of these samples promoted the improvement of the results and the samples presenting the least similarity inside their group were chosen, in order to enhance the accuracy of the analysis, by raising similarity and diminishing the Euclidean distance among samples.

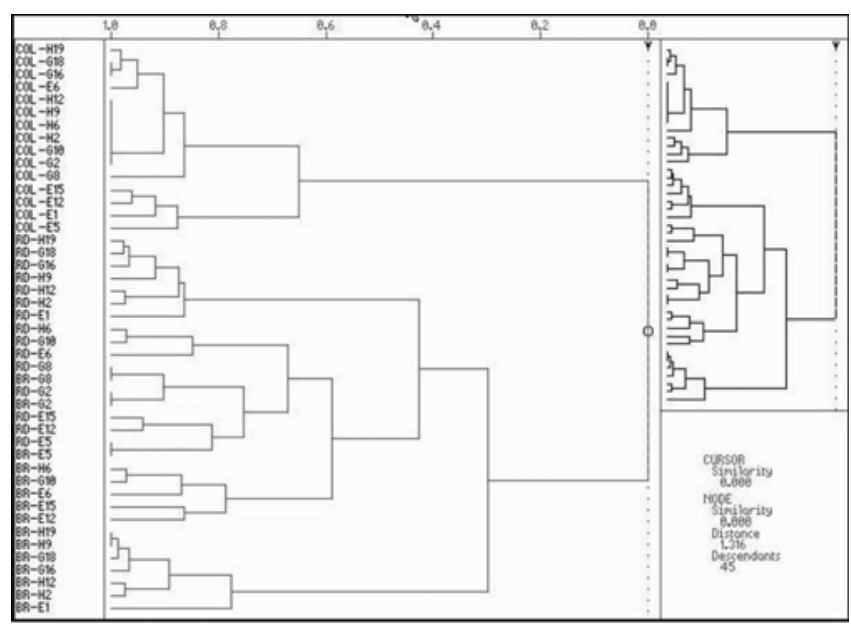

Figure 1. Relationships among American populations of horn fly generated by principalities components using the selected primers. 


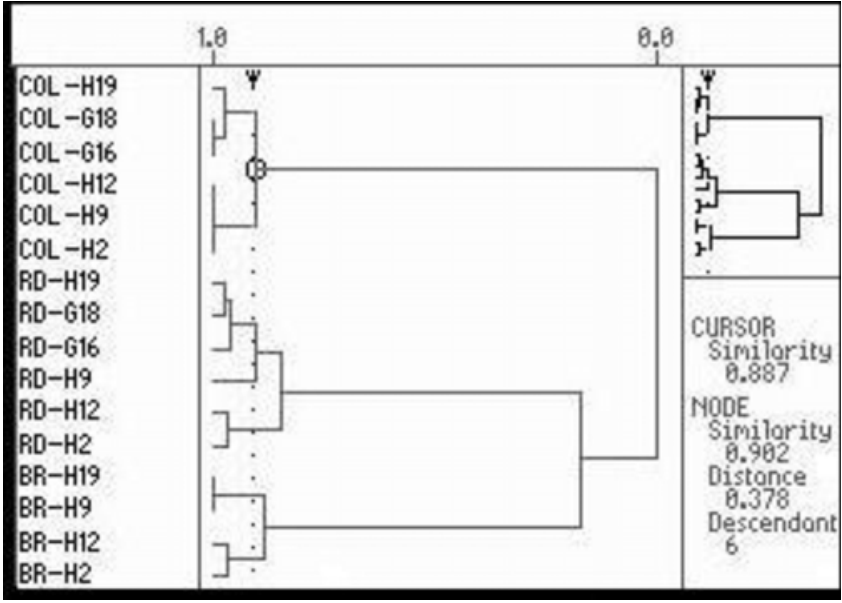

Figure 2. Relationships among American populations of horn fly based on principalities components after the exclusion of the outlier primers.

The hierarchical group analysis shows that Colombia (CO) was the farthest population, presenting zero similarity to the others, while the closest populations were Brazil and Dominican Republic with 0.250 similarity (Figure 2). The similarity between $\mathrm{BR} / \mathrm{DR}$ groups share approximately $25 \%$ of nucleotide sequences complementary to the selected primers, which promotes the genotype distinction among American populations from different geographical origins.

The Penrose and Mahalanobis tests also demonstrated that the genotypically most similar populations were Brazil (BR) and Dominican Republic (DR) (Table 2). The mating among the populations of horn fly from the Brazil (BR) and Dominican Republic (RD) generate individuals that share nucleotide sequences, a fact that does not occur among the populations of Colombia (CO) and Dominican Republic (DR), which share just a few nucleotide sequences.

This result suggests a low contact among the horn fly populations of Brazil and Colombia, a consequence of the

Table 2. Comparison among the American populations of horn fly through the Penrose and Mahalanobis tests.

\begin{tabular}{lccc}
\hline \multicolumn{1}{c}{ Test } & $\begin{array}{c}\text { Brazil } \\
(\mathrm{BR})\end{array}$ & $\begin{array}{c}\text { Dominican } \\
\text { Republic(DR) }\end{array}$ & $\begin{array}{c}\text { Colombia } \\
(\mathrm{CO})\end{array}$ \\
\hline Penrose & - & - & - \\
BR & 0 & - & - \\
RD & 0.0003 & 0 & - \\
CO & 0.1140 & 0.1267 & 0 \\
Greatest distance & 0,1267 & - & - \\
$\quad$ (CO and DR) & & - & - \\
Least distance & 0.0003 & - & - \\
(BR and DR) & - & - & - \\
Mahalanobis: & - & - & - \\
BR & 0 & 0 & - \\
RD & 0.0003 & 0.1267 & 0 \\
CO & 0.1140 & - & - \\
Greatest distance & 0,1267 & - & - \\
(CO and DR) & & & \\
Least distance & 0.0003 & & \\
(BR and DR) & & & \\
\hline
\end{tabular}

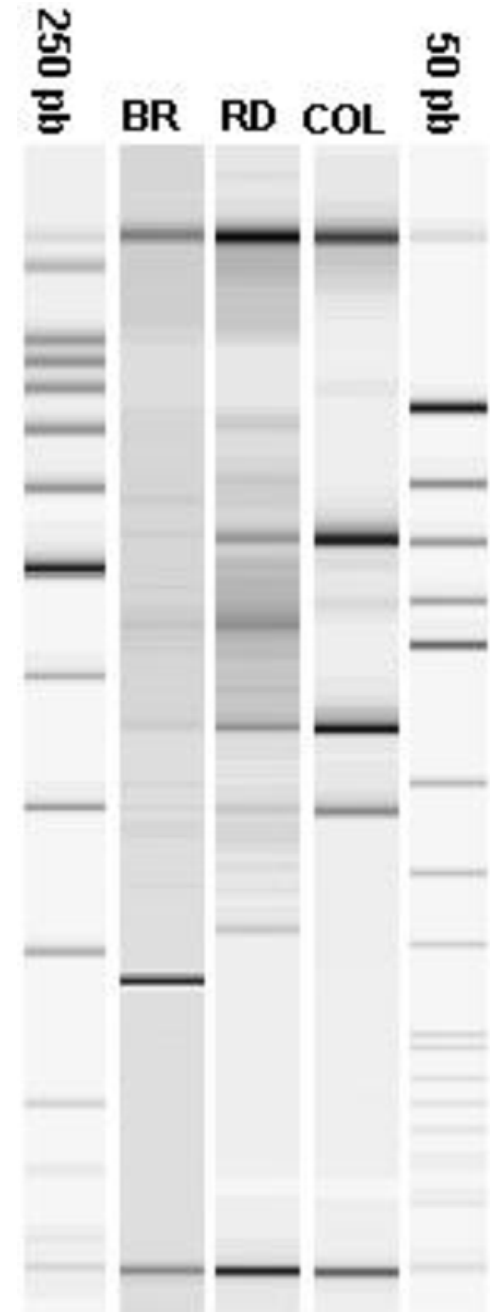

Figure 3. RAPD analyzes obtained from OpH19 primer for populations of horn fly from Brazil (BR), Dominican Republic (RD) and Colombia (COL).

low existing trade of animals between these two countries. Colombia is not an important country in trade cattle for American countries at this moment. The important fact observed in this study was the high genetic flow with Brazilian and Dominican Republic populations of horn fly populations when compared to Colombian population of horn fly, what suggested that gene flow occurred in one moment or, the origin of the Brazilian population of horn fly is the same of Dominican Republic population of $H$. irritans.

Through the main component analysis it was possible to observe that the American populations of horn fly showed polymorphic loci able to characterize them genotipically through the $\mathrm{OpH} 2, \mathrm{OpH} 9, \mathrm{OpH} 12, \mathrm{OpH} 19, \mathrm{OpG} 16$ and OpG18 primers. The primer were best characterized the different American populations of horn fly was OpH19 (Figure 3), once it generated a single genotype pattern for each one of populations studied, being the best molecular marker that excelled the geographic origin of the samples. In the present study analysis of the RAPD products used as molecular markers for identify the geographical origin of the samples of 
horn fly confirmed the high-resolution capacity and sensitivity found in previous investigations (VALENTINI et al., 1996).

A RAPD locus as described here consists of a set of comigrating RAPD fragments amplified by the same RAPD primer (SKROCH; NEINHUIS, 1995) Here, by repeated analysis of single RAPD-PCR samples during the evaluation of the procedure, a length-dependent variation was observed in calculated sizes of individual bands in a range as described earlier (PANARO et al., 2000). In contrast, the pattern of the graphical image generated by the RAPD-PCR fragments during repeated runs of same samples was consistent. Previous populations analysis of parasites by RAPD-PCR demonstrated that this method was suitable for characterize different populations (PAVLICEK et al., 1999, HAMPL et al., 2001, POSEDI et al., 2004).

In the present investigation, American populations of horn fly could be assigned by the analysis of RAPD-PCR products from samples of flies were shown to be capable of distinguishing the geographical origin of the horn fly. In other study conducted by CASTIGLIONI-RUIZ (2001) using the products of RAPD-PCR, which compared different horn fly populations from the states of São Paulo, Mato Grosso do Sul and Acre, accompanied by an American sample from Texas, the author could not observed polymorphic loci able to characterizing genotipically the geographic origin of samples studied, where they presented high indexes of similarity between the samples. The fact that the genetic comparison based on the RAPD-PCR product showed that the American horn fly populations which there were closely relation were Brazil (BR) and Dominican Republic (DR), and this fact can be explained by the genetic flows between these populations maybe for the animal trade, but news studies will be done for explain this high genetic similarity in these populations.

\section{REFERENCES}

AYRES, M.; AYRES Jr M.; AYRES, D.L.; SANTOS, A.S. BioEstat. Versão 2.0, Belém: Sociedade Civil Mamirauá, MCT-CNPq, 2000. 148 p.

BYFORD, R.L.; CRAIG, M.E.; CROSBY, B. A review of ectoparasites and their effect on cattle production. Journal of Animal Science, v. 70, n. 2, p. 597-602, 1992.

CAMPBELL, J.B.; THOMAS, G.D. The history, biology, economics, and control of the Horn Fly, Haematobia irritans. Agri-practice, v. 13, n. 4, p. 31-36, 1992.

CASTIGLIONI-RUIZ, L., 2001. Caracterização molecular de populações de Haematobia irritans (mosca do chifre), pela técnica de RAPD-PCR. 2001. 111 f. Tese (Doutorado) Universidade Estadual de São Paulo, São José do Rio Preto, 2001.

DELLAPORTA, S.L.; WOOD, J.; HICKS, J.B. A plant DNA minipreparation: version II. Plant Molecular Biology Reproductions, v. 1, n. 4, p. 19-21, 1983.

DRUMMOND, R.O. Economic aspects of ectoparasites of cattle in North America. In: SYMPOSIUM OF THE
WORLD VETERINARY CONGRESS, 23,1987, Montreal. Proceedings... Montreal: WVA.1987. p.9-24.

GUGLIELMONE, A.A.; GIMENO, E.; DIART, J.; FISHER, W.F.; VOLPOGNI, M.M.; QUAINO, O.; ANZIANI, O.S.; FLORES, S.G.; WARNKE, O. Skin lesions and cattle hide damage from Haematobia irritans infestations. Medical Veterinary Entomology, v. 13, n. 3, p. 323-328, 1999.

HAMPL, V.; PAVLICEK, A.; FLEGR, J. Construction and bootstrap analysis of DNA fingerprinting-based phylogenetic trees with the freeware program FreeTree: Application to trichomonad parasites. International Journal of Systematic and Evolution Microbiology, v. 51, n. 3, p. 731-735, 2001.

JACCARD, P. Estude comparative de la distribution florale dans portion des Alpes et des Jura. Bulletin de la Société Vaudoise des Sciences Naturelles, v. 37, p. 547-579, 1901.

KUNZ, S.E.; MURREL, K.D.; LAMBERT, G.; JAMES, L.F.; TERRILL, C.E. Estimated losses of livestock to pests. In: PIMENTEL, D. CRC Handbook of Pest Management in Agriculture, Boca Raton: CRC Press, 1991. v. 1, p. 69-98.

PALMER, W.B.; BAY, D.E. A review of the economic importance of the horn fly, Haematobia irritans irritans (L.). Protection Ecology, v. 3, p. 237-244, 1981.

PANARO, N.J.; YUEN, P.K.; SAKAZUME, T.; FORTINA, P.; KRICKA, L.J.; WILDING, P. Evaluation of DNA fragment sizing and quantification on by the Agilent 2100 bioanalyzer. Clinical Chemistry, v. 46, n. 11, p. 851-853, 2000.

PAVLICEK, A.; HRDA, S.; FLEGR, J. Free-Tree-freeware program for construction of phylogenetic trees on the basis of distance data and bootstrap/jackknife analysis of the tree robustness. Application in the RAPD analysis of genus Frenkelia. Folia Biologica, v. 45, n. 3, p. 97-99, 1999.

POSEDI, J.; DRÖGEMÜLLER, M.; SCHNIEDER, T.; HÖGLUND, J.; LICHTENFELS, J.R.; SAMSONHIMMELSTJERNA, G. Microchip capillary electrophoresis-based genetic comparison of closely related cyathostomin nematode parasites of horses using randomly amplified polymorphic DNA polymerase chain reaction. Parasitology Research, v. 92, n. 5, p. 421-429, 2004.

RODERICK, G.K. Geographic structure of insect populations: Gene flow, Phylogeography, and their uses. Annual Review Entomology, v. 41, p. 325-352, 1996.

ROHLF, F.J. NTSYS-PC: Numerical taxonomy and multivariate analysis system: version 1.7. New York : Exeter Software, 1992. 236 p.

SKROCH, P.; NEINHUIS, J. Qualitative and quantitative characterization of RAPD variation among snap bean (Phaseolus vulgaris) genotypes. Theoretical and Applied Genetics, v. 91, n. 6-7, p. 1078-1085, 1995.

STEELMAN, C.D.; BROWN, A.H.; GBUR, E.E.; TOLLEY, G. Interactive response of the horn fly (Diptera: Muscidae) and selected breeds of beef cattle. Journal of Economic Entomology, v. 84, n. 4, p. 1275-1282, 1991.

VALENTINI, A.; TIMPERIO, A.M.; CAPPUCCIO, I.; 
ZOLLA, L. Random amplified polymorphic DNA (RAPD) interpretation requires a sensitive method for the detection of amplified DNA. Electrophoresis, v. 17, n. 10, p. 15531554, 1996.

VALÉRIO, J.R;, GUIMARÃES, J.G. Sobre a ocorrência de uma nova praga, Haematobia irritans (L.) (Diptera:
Muscidae), no Brasil. Revista Brasileira de Zoologia, v. 1, n. 4, p. 417-418, 1983.

WILLIAMS, J.G.K.; KUBELIK, A.R.; LIVAK, K.J. RAFASLKI, J.A.; TINGEY, S.V. DNA polymorphisms amplified by arbitrary primers are useful as genetic markers. Nucleic Acids Research, v. 18, n. 22, p. 6531-6535, 1990.

Recebido em 27 de julho de 2006.

Aceito para publicação em 10 de novembro de 2008. 